\title{
Malignant mesothelioma in women
}

\author{
A Dawson, A R Gibbs, F D Pooley, D M Griffiths, J Hoy
}

\begin{abstract}
Background Malignant mesothelioma reportedly shows different epidemiology and pathology in females, and a proportion are believed to arise spontaneously. Methods One hundred and seventy seven cases of malignant mesothelioma in females were reviewed, examined by histochemistry and immunohistochemistry, assessed for asbestosis and lung fibre burden by transmission electron microscopy with energy dispersive $x$ ray analysis, and compared with 31 female controls.
\end{abstract}

Results Two of one hundred and three cases tested for carcinoembryonic antigen were positive and were excluded from further analysis. Tumour cases showed increased amphibole burdens; in those in whom exposure information was known, $74(80 \%)$ of 93 patients had a history of exposure to asbestos. Seventy two $(47 \%)$ of 152 patients had lung fibrosis. Tumour site and histological type were little different from those reported in adult males. Mixed type histological pattern, lung fibrosis, and peritoneal site were associated with heavier lung asbestos burdens, but not exclusively. Thirty five (30\%) of 117 patients had amphibole burdens of less than $2 \times 10^{6}$ fibres/g; the sites affected and the histological pattern of tumours in this group were similar to those in cases with amphibole fibre counts of $\geqslant 2 \times 10^{6} / \mathrm{g}$ lung. A higher lung amphibole burden than the mean burden in control females was found in $115(98 \%)$ of 117 patients tested.

Conclusions The pathology of malignant mesothelioma appears to be similar in women and in men, and in cases associated and unassociated with asbestos.

(Thorax 1993;48:269-274)

Group, Department of

Histopathology,

Llandough Hospital,

Penarth, South

Glamorgan CF6 1XX

A Dawson

A R Gibbs

J Hoy

Department of

Mining, University

College, Cardiff,

South Glamorgan, UK

F D Pooley

D M Griffiths

Reprint requests to:

Dr A Dawson

Received 9 March 1992

Returned to authors

8 May 1992

Revised version received

Revised version

Accepted 25 August 1992

Malignant mesothelioma in females is well recognised, although there has been only one exclusively female series (of 52 cases) previously reported. ${ }^{1}$ Published material indicates that it is $2-10$ times less common in females, ${ }^{23}$ although in populations which have little or no exposure to asbestos the incidence is more equal. ${ }^{*}$ The static incidence rate of malignant mesothelioma in females compared with the rising incidence in males (related to the use of asbestos in industry) has led to suggestions that a significant proportion of the tumours in women are "spontaneously occurring" and unrelated to asbestos exposure. The proportion of cases of malignant mesothelioma with a history of occupational exposure to asbestos is less in women than in men, varying from $5.4 \%$ in women and $40 \%$ in men in Quebec ${ }^{5}$ to $17 \%$ in women and $82 \%$ in men in Norway. Occupational histories may overestimate or underestimate exposure to asbestos depending on the types of cases involved and the rigour of the investigations. Mineralogical evaluation of lung tissues is extremely helpful in verifying or refuting the accuracy of occupational exposures. To date there have been few published data in female cases of malignant mesothelioma.

The proportion of cases of malignant mesothelioma affecting the peritoneum is reported to be greater in females, ${ }^{78}$ ranging from $15 \%$ in females and $7 \%$ in males in a review of 4710 cases, ${ }^{9}$ to $39 \%$ in North American females and $22 \%$ in males. ${ }^{10}$ However, a UK series of 246 cases showed almost identical site distributions in both sexes. ${ }^{11}$ Histological subtyping showed no significant differences between males and females in two UK series, ${ }^{12}{ }^{13}$ but one study of pleural tumours showed the epithelial type to represent a greater proportion in females $(76 \%)$ than males $(37 \%),{ }^{14}$ and this preponderance of epithelial type was also seen in a Canadian study (females 59\%; males 39\%). ${ }^{15}$ Differential exposure to different types of amphiboles has been proposed to explain these differences, but again with little or no corroboration by mineral analysis of lung fibre burdens.

In this study of 177 women we examined the histopathology of malignant mesothelioma and measured the mineral fibre content of their lungs by transmission electron microscopy (TEM) with energy dispersive $x$ ray analysis using an "EDAX" machine. The lung fibre counts were compared with those in 31 female controls. To the best of our knowledge this is the largest series reported.

The objectives of the study were to deter-

\section{Methods}

MATERIALS

All available pathological, occupational and mineralogical data on 177 female cases classified as malignant mesothelioma in the files of 
this unit over the period 1963-1990 were reviewed (during this period 1184 male cases were classified). The cases were largely referred as wet lung/tumour tissue or as slides or blocks, often for histological confirmation of diagnosis. Twenty six cases had no tumour tissue or slides for review; these cases were originally classified by Dr JC Wagner and his record of histological pattern was used for our analysis. Of the remaining 151 cases, $22 \%$ had six or more histological slides or blocks available for study, $63 \%$ had three or more, and $85 \%$ had two or more. Thirty one women from five series of consecutive post mortem examinations on patients with no known history of exposure to dusts, and no mesothelioma or lung cancer, from Exeter, Liverpool, Belfast, Dublin, and Cardiff, were used as controls. These were, of necessity, unmatched.

\section{STUDY DESIGN}

Histological slides of each tumour were stained with haematoxylin and eosin and examined and, where possible, the tumour was stained for glycogen (PAS) and neutral mucin (PASD). Immunohistochemistry was performed to detect cytokeratin and carcinoembryonic antigen by peroxidase conjugated avidin biotin staining (Broad spectrum keratin "CKKES" and CEA "CKCES," Diagnostic Products Corporation, Los Angeles, USA). Malignant mesotheliomas were assigned to epithelial, spindle (connective tissue, sarcomatoid) or mixed histological subtypes. Background lung was stained with haematoxylin/van Gieson where possible, and fibrosis was assessed and graded according to the method of Hinson et al. ${ }^{16}$ A search for asbestos bodies was carried out on conventionally stained $5 \mu \mathrm{m}$ sections.

TEM was performed according to the method of Pooley and Clark. ${ }^{17}$ Briefly, nontumourous lung was digested in $40 \%$ potassium hydroxide, washed, and ashed in an atmosphere of oxygen. Digested lung residues were filtered on to Millipore filters and carbon coated; 100-200 fibres were individually identified by energy dispersive $x$ ray analysis and the proportions of each different fibre type in the digest were calculated. Fibre length and diameter were measured directly from the screen at a magnification of $\times 20000$.

Exposure to asbestos was classified according to Zielhuis ${ }^{18}$ into (1a) direct occupational exposure; (1b) indirect occupational exposure-for example, workers in the vicinity of asbestos contaminated work situations; (2) paraoccupational exposure-for example, the wives of men working with asbestos; (3) neighbourhood exposure-for example, people living in the vicinity of asbestos mines or processing factories; (4) exposure in ambient air; (5) no known exposure.

\section{Results}

AGE

The mean age for the 102 cases of malignant mesothelioma of known age was 60.5 (range 18-89) years and for the 31 controls was 68 (range 30-93) years.

\section{HISTOLOGY AND SITE (TABLE 1)}

Review of the stained slides of the 151 cases for which tumour tissue was available showed evidence of malignant mesothelioma in all cases. Two of one hundred and three cases (2\%) tested for carcinoembryonic antigen were positive and were excluded from further analysis.

Of the remaining 175 cases, $125(71 \%)$ were positive, tumours were pleural (mean age 62 years), $29(17 \%)$ were peritoneal (mean age 56 years), and 21 were of unknown site. The histological profile for tumours of known histology was $54 \%$ epithelial, $33 \%$ mixed, $13 \%$ spindle.

Of the 131 tumours stained for glycogen and mucin, $45(34 \%)$ were positive for glycogen $(37 \%$ of epithelial tumours and $23.5 \%$ of spindle tumours) and none for mucin. Psammoma bodies were seen in five $(3 \%)$ of 175 cases (three pleural and two peritoneal, three of epithelial and two of mixed type).

Of 101 tumours analysed for cytokeratin, $90(89 \%)$ were positive. Cytokeratin was more common in epithelial (51 of 53) than spindle (11 of 15) tumours; 28 of 33 mixed tumours were positive for cytokeratin, and in the 25 cases in which both elements were included in the section stained both elements were positive in 14 and the epithelial element only in 11 .

MINERAL ANALYSIS OF CASES AND CONTROLS (TABLE 2)

Of the cases of malignant mesothelioma, $98 \%$ had lung amphibole counts greater than the mean count in the controls; $78 \%$ of all cases of malignant mesothelioma had lung amphibole counts greater than $1 \times 10^{6}$ fibres/g dried lung and $89 \%$ of these had lung amphibole counts greater than $2 \times 10^{6}$ fibres/g dried lung.

Of the 105 tumours of known site from which lung tissue was examined by TEM, the

Table 1 Histological pattern of mesotheliomas according to site and amphibole burden

\begin{tabular}{llllll}
\hline \multicolumn{5}{c}{ Histological type (\%) } \\
\cline { 2 - 6 } Category & $n$ & Epithelial & Mixed & Connective tissue & Unknown type \\
\hline All & $175^{\star}$ & 48 & 30 & 12 & 10 \\
Pleural & 125 & 51 & 33 & 14 & 2 \\
Peritoneal & 29 & 59 & 24 & 10 & 6 \\
$<2 \times 10^{\circ}$ amphiboles/g & 35 & 57 & 32 & 12 & 17 \\
$\geqslant 2 \times 10^{6}$ amphiboles/g & 82 & 39 & 32 &
\end{tabular}

*Two cases positive for carcinoembryonic antigen excluded. 
Table 2 Lung fibre burdens ( $\times 10^{\circ}$ fibres/g lung) in controls and patients with mesothelioma according to site, expressed as geometric mean (range)

\begin{tabular}{lcccc}
\hline & \multicolumn{4}{l}{ Mesothelioma } \\
\cline { 2 - 5 } Lung fibres & $\begin{array}{l}\text { Control } \\
(n=31)\end{array}$ & $\begin{array}{l}\text { All } \\
(n=117)^{*}\end{array}$ & $\begin{array}{l}\text { Pleural } \\
(n=98)\end{array}$ & $\begin{array}{l}\text { Peritoneal } \\
(n=7)\end{array}$ \\
\hline Total amphiboles & $0.04(0-1 \cdot 0)$ & $10 \cdot 1(0-2888)$ & $7 \cdot 3(0 \cdot 10-2888)$ & $221(1 \cdot 3-2353)$ \\
$\quad$ Crocidolite & $0.02(0-0 \cdot 50)$ & $5 \cdot 1(0-2888)$ & $3 \cdot 4(0-2888)$ & $175(0-2353)$ \\
Amosite & $0.02(0-0 \cdot 50)$ & $0.09(0-2420)$ & $0 \cdot 09(0-2420)$ & $1 \cdot 1(0-12 \cdot 8)$ \\
$\quad$ Tremolite & $0 \cdot 02(0-0 \cdot 80)$ & $0.03(0-120)$ & $0 \cdot 03(0-120)$ & $0 \cdot 11(0-1 \cdot 6)$ \\
Chrysotile & $4 \cdot 4(0-20 \cdot 1)$ & $7 \cdot 1(0-2506)$ & $6 \cdot 7(0-2506)$ & $1 \cdot 1(3 \cdot 2-49 \cdot 2)$ \\
Total fibres & $10.5(0-83 \cdot 1)$ & $77 \cdot 5(1 \cdot 2-3105)$ & $67 \cdot 6(1 \cdot 2-3105)$ & $365(25 \cdot 2-2370)$ \\
\hline
\end{tabular}

$\star 12$ cases of unknown site.

peritoneal group showed a higher amphibole burden than the pleural group. One hundred and one cases of known histological type underwent TEM; the highest amphibole burdens were seen in those cases exhibiting the mixed pattern, with those of spindle pattern showing the lightest burdens.

The site and histological profile of the group with total amphibole counts of $<2 \times 10^{6}$ fibres/g dried lung differed little from those with amphibole counts of $\geqslant 2 \times 10^{6}$ fibres/g dried lung (table 1), apart from the slight preponderance of mixed histological pattern in those with heavier fibre burdens.

Six specimens contained only amosite as their amphibole burden. One specimen, from a Turkish peasant girl from the western part of central Anatolia, contained high levels of tremolite and erionite. Twenty eight cases contained over $30 \times 10^{6}$ fibres/g lung tissue of chrysotile; all but four of these also contained over $2 \times 10^{6}$ amphibole fibres/g dried lung. Traces of amphiboles (from 0.4 to $1.8 \times 10^{6}$ amphibole fibres/g dried lung) were found in the remaining four cases with high chrysotile counts.

There were too few cases to permit an assessment of the influence of any one fibre type on site or pattern, independently of other fibre types.

\section{ASBESTOS BODIES}

One hundred and thirty three cases were assessed by light microscopy for the presence of asbestos bodies in background lung; 70
(53\%) were positive. In the 49 specimens positive for asbestos bodies that subsequently underwent examination by TEM, the lowest total amphibole count was $2.2 \times 10^{6}$ fibres/g dried lung tissue. On the other hand, in the 63 specimens with no asbestos bodies, 50 subsequently underwent TEM and 23 of these had total amphibole counts over $2 \times 10^{6}$ fibres/g dried lung tissue.

\section{FIBROSIS (TABLE 3)}

Fibrosis was graded in background lung for 152 cases and 31 controls. No fibrosis was found in 26 controls, four showed grade 1 fibrosis, and one control (with cryptogenic fibrosing alveolitis) had grade 4 fibrosis. More severe fibrosis in patients with malignant mesothelioma was associated with increasing amphibole and total fibre counts, an increase in peritoneal site in relation to pleural site, and an increase in mixed histological type over epithelial and spindle types. The three cases with grade 4 fibrosis had a mean age at death of 46.5 years (14 years younger than the malignant mesothelioma patients as a whole).

\section{OCCUPATIONAL EXPOSURE HISTORY}

Occupational/exposure history, classified according to Zielhuis, is given in table 4 . All those peritoneal tumours for which exposure information was available were in the occupationally exposed group (group 1a). The paraoccupational group (group 2) showed an increase in the proportion of tumours of mixed type (and to a lesser extent of those of

Table 3 Site of mesothelioma, histological pattern and lung fibre burden $\left(\times 10^{6}\right.$ fibres $/ g$ lung expressed as geometric mean (range)) according to lung fibrosis grade

\begin{tabular}{|c|c|c|c|c|c|}
\hline & \multicolumn{5}{|l|}{ Fibrosis grade } \\
\hline & 0 & 1 & 2 & 3 & 4 \\
\hline \multicolumn{6}{|l|}{ Site and pattern: } \\
\hline $\mathrm{n}$ & 80 & 34 & 25 & 10 & 3 \\
\hline Pleural (\%) & $66(83)$ & $27(79)$ & $22(88)$ & $5(50)$ & 0 \\
\hline Peritoneal (\%) & $6(8)$ & $4(12)$ & $3(12)$ & $3(30)$ & $3(100)$ \\
\hline Unknown site & 8 & 3 & 0 & 2 & 0 \\
\hline Epithelial (\%) & $39(49)$ & $16(47)$ & $12(48)$ & $3(3)$ & $1(33)$ \\
\hline Mixed $(\%)$ & $20(25)$ & $13(38)$ & $7(28)$ & $4(40)$ & $2(67)$ \\
\hline Connective tissue $(\%)$ & $11(14)$ & $3(9)$ & $5(20)$ & 0 & 0 \\
\hline Unknown pattern & 10 & 2 & 1 & 3 & 0 \\
\hline \multicolumn{6}{|l|}{ Mineral analysis: } \\
\hline n & 61 & 24 & 23 & 8 & 0 \\
\hline Total amphiboles & $3 \cdot 9(0 \cdot 10-2888)$ & $16 \cdot 2(0 \cdot 50-823)$ & $33 \cdot 2(0 \cdot 20-2420)$ & $112(0.50-2353)$ & - \\
\hline Crocidolite & $2 \cdot 0(0-2888)$ & $8 \cdot 0(0-823)$ & $13 \cdot 8(0-1693)$ & $105(0-2353)$ & - \\
\hline Amosite & $0.06(0-7.9)$ & $0 \cdot 11(0-2 \cdot 2)$ & $0 \cdot 21(0-2420)$ & $0.05(0-16 \cdot 2)$ & - \\
\hline Tremolite & $0.02(0-7.0)$ & $0.07(0-120)$ & $0 \cdot 05(0-41 \cdot 0)$ & $2 \cdot 8(0-20 \cdot 6)$ & - \\
\hline Chrysotile & $6 \cdot 4(0-1118)$ & $10 \cdot 4(0-2506)$ & $6.0(0-344)$ & $25 \cdot 2(0-1541)$ & - \\
\hline Total fibres & $50 \cdot 6(1 \cdot 2-3105)$ & $93 \cdot 0(7 \cdot 3-2566)$ & $119(5 \cdot 9-2444)$ & $402(17 \cdot 40-2377)$ & - \\
\hline
\end{tabular}


Table 4 Site of mesothelioma, histological pattern and lung fibre burden ( $\times 10^{6}$ fibres/g expressed as geometric mean (range)) according to type of

\begin{tabular}{|c|c|c|c|c|c|c|}
\hline & \multicolumn{6}{|c|}{ Exposure group (Zielhuis) } \\
\hline & $\begin{array}{l}\text { 1a } \\
\text { Direct occupational }\end{array}$ & $\begin{array}{l}1 b \\
\text { Indirect occupational }\end{array}$ & $\begin{array}{l}2 \\
\text { Domestic }\end{array}$ & $\begin{array}{l}3 \\
\text { Neighbourhood }\end{array}$ & 4 & $\begin{array}{l}5 \\
\text { No known exposure }\end{array}$ \\
\hline \multicolumn{7}{|l|}{ Site and pattern: } \\
\hline $\mathrm{n}$ & 38 & 13 & 15 & 6 & 2 & 19 \\
\hline Pleural (\%) & $27(71)$ & $11(85)$ & $14(93)$ & $5(83)$ & $1(50)$ & $16(84)$ \\
\hline Peritoneal (\%) & $5(13)$ & 0 & 0 & 0 & 0 & 0 \\
\hline Unknown site & 6 & 2 & 1 & 1 & 1 & 3 \\
\hline Epithelial (\%) & $16(42)$ & $5(38)$ & $4(27)$ & $4(67)$ & $1(50)$ & $9(47)$ \\
\hline Mixed (\%) & $8(21)$ & $5(38)$ & $7(47)$ & $2(33)$ & 0 & $5(26)$ \\
\hline Connective tissue( $\%)$ & $4(11)$ & $1(8)$ & $3(20)$ & 0 & $1(50)$ & $3(16)$ \\
\hline Unknown pattern & 10 & 2 & 1 & 0 & 1 & 2 \\
\hline \multicolumn{7}{|l|}{ Mineral analysis: } \\
\hline $\mathrm{n}$ & 34 & 12 & 14 & 2 & 2 & 14 \\
\hline Total amphiboles & $27 \cdot 0(0 \cdot 10-2420)$ & $6.3(0.50-28 \cdot 3)$ & $4.9(0-251)$ & $2 \cdot 0(0 \cdot 80-5 \cdot 1)$ & $11 \cdot 0(1 \cdot 0-120)$ & $1 \cdot 3(0 \cdot 20-107)$ \\
\hline Crocidolite & $13.9(0-1542)$ & $5 \cdot 2(0 \cdot 50-28 \cdot 3)$ & $1.9(0-251)$ & $2 \cdot 0(0 \cdot 80-5 \cdot 1)$ & $0.29(0.09-0.90)$ & $0.57(0-101)$ \\
\hline Amosite & $0 \cdot 12(0-2420)$ & $0.25(0-4.6)$ & $0 \cdot 22(0-6 \cdot 1)$ & 0 & $0.03(0.01-0.10)$ & $0 \cdot 21(0-4 \cdot 6)$ \\
\hline Tremolite & $0.02(0-41.0)$ & 0 & $0.20(0-29 \cdot 3)$ & 0 & $39 \cdot 3(12 \cdot 8-120)$ & $0.04(0-1.8)$ \\
\hline Chrysotile & $5.9(0-1541)$ & $16.9(0-1118)$ & $12 \cdot 7(0-2506)$ & $8.5(8 \cdot 2-8 \cdot 9)$ & $0.47(0.15-1.5)$ & $3.9(0-135)$ \\
\hline Total fibres & $108(7 \cdot 3-2444)$ & $72 \cdot 1(18 \cdot 3-1529)$ & $64 \cdot 1(5 \cdot 6-2566)$ & $15 \cdot 7(14 \cdot 6-16 \cdot 9)$ & $81 \cdot 5(6 \cdot 6-1006)$ & $22.9(1 \cdot 2-194)$ \\
\hline
\end{tabular}

spindle type), with a reduction in the proportion of epithelial type. The lowest mean age of death was seen in the neighbourhood exposure group ( 48.5 years), again 12 years younger than the malignant mesothelioma group of patients as a whole.

Measurements of 78 cases with exposure information showed the heaviest amphibole burden in those cases with direct occupational exposure. Only one of the 14 cases with no history of exposure had lung containing no amphiboles, and four of the 14 had total amphibole counts of $\geqslant 2 \times 10^{6}$ fibres $/ g$ dried lung tissue.

\section{Discussion}

The interpretation of the results of the histological and mineralogical data provided by this study must be tempered by the knowledge that it is a referred population, and therefore not completely representative of any community over the period studied. It is also heavily biased by the inclusion of groups such as wartime dockyard and gas mask workers, who suffered very heavy exposure to asbestos. The study is further restricted by deficiencies in the amount of material available for study, and in the completeness of exposure data and other information for which we were dependent on our referring bodies. These limitations notwithstanding, the study provides the largest database of malignant mesothelioma in females yet reported.

\section{HISTOLOGICAL DIAGNOSIS}

It is not surprising that review of the tumour histology confirmed appearances consistent with the diagnosis of malignant mesothelioma, since all cases were seen by at least one pathologist from this unit with considerable experience in the diagnosis of malignant mesothelioma before classification in our files. The diagnosis of malignant mesothelioma is further supported by the absence of neutral mucin ${ }^{19}$ and carcinoembryonic antigen $^{20-22}$ in those tested.

Our finding of $89 \%$ positivity for cytoker- atin is similar to reported data. ${ }^{23}$ The preferential finding of positivity in the epithelial component in those of mixed histological pattern has also been reported by Montag et $a l^{4}$ and Corson and Pinkus. ${ }^{25}$

SITE AND HISTOLOGICAL SUBTYPE

Despite the referred nature of the series, the histological profile of our cases for each site and overall mirrors those given in the literature review of Hillerdal $^{9}$ and is not strikingly different from those in other reported series (table 5). The predominance of the epithelial pattern in women with pleural malignant mesothelioma reported by the Mayo Clinic ${ }^{14}$ does not seem to be reflected in our study.

The suggestion in one series ${ }^{30}$ that all cases of malignant mesothelioma occurring in patients with no history of exposure are of epithelial pattern is not borne out by our finding of $47 \%$ epithelial: $26 \%$ mixed: $16 \%$ spindle pattern in 19 cases in Zielhuis group 5 (table 4).

The higher amphibole burden found in patients with peritoneal tumours (table 2 ) is similar to the findings of McDonald et al in North America ${ }^{31}$ and those of Wagner $e t$ al in East London asbestos factory workers. ${ }^{32}$

The reason for the high proportion of peritoneal malignant mesotheliomas in females in the literature is uncertain. If the peritoneal site is indeed favoured only after the development of asbestosis, it would seem to represent an excess in a gender with usually less heavy non-occupational exposure to asbestos. It may be that, despite care in the histological diagnosis, researchers have included tumours mimicking malignant mesothelioma (such as tumours of the extraovarian Mullerian system or endosalpingosis) ${ }^{33} 34$ that are unique to women. If this were the case, a large TEM study of peritoneal cases would be expected to show a dual population-those true cases of malignant mesothelomas, probably also with related asbestosis, would have high asbestos burdens while cases of endosalpingosis would have counts similar to those of controls. Unfortunately, only seven of our 29 
Table 5 Histological pattern according to site, and comparison with published material

\begin{tabular}{|c|c|c|c|c|c|c|}
\hline Site & Source (ref) & $n$ & Sex & Epithelial (\%) & Mixed (\%) & Spindle (\%) \\
\hline Overall & $\begin{array}{l}\text { Present study } \\
\text { Literature review }^{9} \\
\text { Canada }^{20} \\
\text { Belfast }^{13} \\
\text { Canada }^{15}\end{array}$ & $\begin{array}{r}158 \\
922 \\
65 \\
184 \\
32 \\
67\end{array}$ & $\begin{array}{l}\text { F } \\
\text { Both } \\
\text { Both } \\
\text { Both } \\
\text { F } \\
\text { M }\end{array}$ & $\begin{array}{l}54 \\
52 \\
46 \\
34 \\
59 \\
39\end{array}$ & $\begin{array}{l}33 \\
33 \\
25 \\
42 \\
35 \\
25\end{array}$ & $\begin{array}{r}13 \\
15 \\
23 \\
24 \\
6 \\
6 \\
36\end{array}$ \\
\hline Pleural & $\begin{array}{l}\text { Present study } \\
\text { Literature review } \\
\text { London }^{27} \\
\text { UK }^{28} \\
\text { Mayo Clinic }\end{array}$ & $\begin{array}{r}122 \\
829 \\
115 \\
23 \\
61 \\
21 \\
71\end{array}$ & $\begin{array}{l}\text { F } \\
\text { Both } \\
\text { NS } \\
\text { F } \\
\text { M } \\
\text { F } \\
\text { M }\end{array}$ & $\begin{array}{l}52 \\
50 \\
52 \\
48 \\
38 \\
76 \\
37\end{array}$ & $\begin{array}{l}34 \\
34 \\
26 \\
39 \\
29 \\
14 \\
38\end{array}$ & $\begin{array}{l}14 \\
16 \\
22 \\
13 \\
33 \\
10 \\
25\end{array}$ \\
\hline Peritoneal & $\begin{array}{l}\text { Present study }{ }^{\star} \\
\text { Literature review }^{9} \\
\text { USA }^{29}\end{array}$ & $\begin{array}{l}27 \\
75 \\
82\end{array}$ & $\begin{array}{l}\text { F } \\
\text { Both } \\
\text { Both }\end{array}$ & $\begin{array}{l}63 \\
60 \\
75\end{array}$ & $\begin{array}{l}26 \\
31 \\
22\end{array}$ & $\begin{array}{r}11 \\
9 \\
2\end{array}$ \\
\hline
\end{tabular}

NS-not stated.

${ }^{\star}$ Cases of unknown pattern excluded.

peritoneal cases had lung tissue available for TEM but, of these, six contained amphibole counts over $100 \times 10^{6}$ fibres/g dried lung. The other case, a worker in an aircraft factory said to be occupationally exposed to asbestos, had $1.3 \times 10^{6}$ amphibole fibres and $9.1 \times 10^{6}$ chrysotile fibres/g dried lung.

\section{FIBROSIS}

Most of our cases of malignant mesothelioma $(73 \%)$ had grade 1 fibrosis or less, which is consistent with reports of malignant mesothelioma developing in dockyard workers at lower fibre burdens and grades of asbestosis than in those dockers with pulmonary carcinoma. ${ }^{35}$ The study of East London asbestos factory workers also showed that malignant mesothelioma was associated with lower mean fibre burdens than was asbestosis alone. ${ }^{32}$

Our study shows that increasing fibrosis is associated with peritoneal site $(p<0.001)$ and increasing amphibole burden, and this is again similar to the study of the asbestos factory workers ${ }^{32}$ and also to a study of asbestos related deaths in the UK in $1977 .{ }^{36}$

In our study (table 3) 13 (68\%) of 19 peritoneal cases had fibrosis compared with 54 $(45 \%)$ of 120 pleural cases; overall, $72(47 \%)$ of the 152 patients in our series had fibrosis. Browne and Smither ${ }^{12}$ found that $28 \%$ of peritoneal cases and $22 \%$ of pleural cases had asbestosis; the higher incidence of fibrosis in our cases may reflect higher lung fibre burdens. Other studies, however, do show a higher incidence of asbestosis in malignant mesothelioma; Kannerstein and Churg found asbestosis in $74 \%$ of their series of peritoneal malignant mesothelioma, ${ }^{29} 52 \%$ of 65 Canadian cases of pleural malignant mesothelioma were affected ${ }^{26}$ and $46 \%$ of a series of 37 pleural cases. ${ }^{37}$

\section{MINERAL ANALYSIS BY TEM}

The high mean amphibole burdens may reflect the high proportion of patients with a history of exposure to asbestos (74 of 93 of those with known history) and the heavy exposures of a large number of the cases. Twenty one of our women were gas mask workers; a further seven (of unclassified ex- posure) represented seven of the eight highest total amphibole burdens in our study (each in excess of $1000 \times 10^{6}$ fibres/g dried lung). As one might expect, studies of occupational groups of workers have shown higher amphibole burdens-for example, gas mask workers, ${ }^{38}$ asbestos process workers, ${ }^{32}$ cement workers, ${ }^{39}$ and textile workers ${ }^{40}$-than were found in a more general survey of patients with malignant mesothelioma. ${ }^{41}$

Only five of 14 patients with no history of exposure were found to have amphibole counts equal to or less than the highest counts in the control series, while four had counts of $\geqslant 2 \times 10^{6}$ fibres $/ g$ dried lung tissue, indicating that occasionally unrecognised exposures occur. These apparent anomalies indicate the inherent unreliability of exposure history and add weight to the recommendation that TEM of lung fibre burdens should be performed in assessing disease association with asbestos exposures. ${ }^{28}$

Of the patients tested in this series, $98 \%$ showed amphibole burdens greater than the mean for the female controls. No amphiboles were detected in $2 \%$ of patients compared with $63 \%$ of controls. This is similar to the findings in a previous UK study of malignant mesothelioma in 1976, which found $5 \%$ of cases with no amphiboles compared with $20 \%$ of controls (males and females). ${ }^{42}$ In this series, $35(30 \%)$ of 117 female patients had amphibole levels lower than $2 \times 10^{6}$ fibres/g dried lung, and these might be considered spontaneously arising tumours. The use of the TEM lung fibre count to define spontaneously arising malignant mesothelioma is difficult and arbitrary, however, because studies of control populations occasionally show counts in the region of $2 \times 10^{6}$ amphiboles $/ g$ dried lung.

Five of our cases with lung fibre counts below $2 \times 10^{6}$ amphiboles/g dried lung had levels of chrysotile higher than the highest control (highest control $20.1 \times 10^{6}$ chrysotile fibres/g dried lung; five cases 21.5-111.7 $\times$ $10^{6}$ chrysotile fibres/g dried lung). There were no cases with a high chrysotile count that did not have contaminating amphiboles, so no cases of malignant mesothelioma could be attributed with certainty to the presence of 
chrysotile alone. In control males, levels of up to $50 \times 10^{6}$ chrysotile fibres/g dried lung are not infrequently encountered. Epidemiologically there have been few cases of malignant mesothelioma associated with pure chrysotile exposure, and these have been attributed to contaminating amphiboles. ${ }^{53-45}$

The two cases with no amphiboles and a chrysotile count similar to control values add to the small number of reports of cases of malignant mesothelioma shown by electron microscopic fibre analysis to have no amphiboles and low chrysotile burden, ${ }^{283642}$ and support the hypothesis that some cases of malignant mesothelioma are not associated with exposure to asbestos. A number of possible alternative aetiologies have been proposed. ${ }^{46}$

This study shows the usefulness of mineral analysis of lung tissues in assessing whether a case of malignant mesothelioma is likely to have been caused by asbestos exposure. The similarity of clinical and pathological features of malignant mesothelioma in women with high and low amphibole burdens indicates that these features alone are not likely to be useful in identifying the spontaneously arising tumour.

This work was carried out as part of Health and Safety Executive Committee Report No $1 / \mathrm{LMD} / 126 / 270 / 88$ Executive Committee Report No 1//
entitled Biological Effects of Mineral Dust.

1 Vianna NJ, Polan AK. Non-occupational exposure to asbestos and malignant mesothelioma in females. Lancet 1978;i:1061-3.

2 Ferguson D, Berry G, Jelihovsky T, Andreas S, Rogers A, Fung SC, et al. The Australian Mesothelioma Fung SC, et al. The Australian Mesothelioma Surveillance Progr

3 Zwi AB, Reid G, Landau SP, Kielkowski D, Sitas P, Becklake MR. Mesotheliomas in South Africa 1976-84 incidence and case characteristics. Int $\mathcal{f}$ Epidemio 1989;18:320-9.

4 Lemesch C, Steinitz E, Wasserman M. Epidemiology of mesotheliomas in Israel. Environ Res 1976;12:255-61.

5 McDonald AD. Malignant mesothelioma in Quebec. In: Wagner JC, ed. Biological effects of mineral fibres. IARC Scientific Publications No 30. Lyon: IARC, 1980:

Mowe G, Gylseth B. Occupational exposure and regional variation of malignant mesothelioma in Norway variation of malignant mesotheliom

7 Selikoff IJ, Hammond EC, Seidman H. Mortality experience of insulation workers in the United States and Canada. Ann NY Acad Sci 1979;330:91-116.

8 Wagner JC, Sleggs CA, Marchand P. Diffuse pleural mesothelioma and asbestos exposure in the North Western Cape Province. Br f Ind Med 1960;17:260-71.

9 Hillerdal G. Malignant mesothelioma 1982: review of 4710 published cases. $B r$ f Dis Chest 1983;77:321-43.

10 McDonald AD, McDonald JC. Malignant mesothelioma in North America. Cancer 1980;46:1650-6.

11 Greenberg M, Lloyd Davies TA. Mesothelioma register 1967-68. Br F Ind Med 1974;31:91-104.

12 Browne K, Smither WJ. Asbestos related mesothelioma: factors discriminating between pleural and peritoneal sites. Br f Ind Med 1983;40:145-52.

13 Elmes PC, Simpson MJC. The clinical aspects of mesothelioma. $Q \mathcal{F}$ Med 1976;179:427-49.

14 Adams VI, Unni KK, Muhm JR, Jett JR, Ilstrup DM Bernatz PE. Diffuse malignant mesothelioma of pleura. Cancer 1986;58:1540-51.

15 Magner D, McDonald AD. Malignant mesothelia tumours: histologic type and asbestos exposure. $N$ Engl f Med 1972;287:570-1.

16 Hinson KFW, Otto H, Webster I, Rossiter CE. Criteria for the diagnosis and grading of asbestosis. In: Bogovski P, ed. Biological effects of asbestos. Lyon: IARC, 1973: 54-7.

17 Pooley FD, Clark NJ. Quantitative assessment of inorganic fibrous particulates in dust samples with an analytic transmission electron microscope. Ann Occup Hyg transmission elect

18 Zielhuis RL. Public health risks of exposure to asbestos. Oxford: Pergamon Press, 1977.
19 Silcocks PB, Herbert A, Wright DH. Evaluation of PAS diastase and carcinoembryonic antigen staining in the differential diagnosis of malignant mesothelioma and papillary serous carcinoma of the ovary. I Pathol 1986;149:133-41.

20 Ordonez NG. The immunohistochemical diagnosis of mesothelioma. Am $\mathcal{7}$ Surg Pathol 1989;13:276-91.

21 Whitaker D, Sterrett GF, Shilkin KB. Detection of tissue CEA-like substance as an aid in the differential diagnosis of malignant mesothelioma. Pathology 1982;14 255-8.

22 Gibbs AR, Harach R, Wagner JC, Jasani B. Comparison of tumour markers in malignant mesotheliomas and pulmonary adenocarcinomas. Thorax $1985 ; 40: 91-5$.

23 Wolf KM, Piotrowski ZH, Engel JD, Bekeris LG, Palacios E, Fisher KA. Malignant mesothelioma with occupational and environmental asbestos exposure in an
Illinois community hospital. Arch Intern Med 1987;147:2145-9.

24 Montag AG, Pinkus GS, Corson JM. Keratin protein immunoreactivity of sarcomatoid and mixed types of diffuse malignant mesothelioma: an immunoperoxidase study of 30 cases. Hum Pathol 1988;19:336-42.

25 Corson JM, Pinkus GS. Mesothelioma: profile of keratin proteins and carcinoembryonic antigen: an immunoperoxidase study of 20 cases and comparison with pulmonary adenocarcinoma. Am f Pathol 1982;108:80-7.

26 McDonald JC, Armstrong B, Case B, Doell D McCaughey WTE, McDonald AD, et al. Mesoth and asbestos fiber type. Cancer 1989;63:1544-7.

27 Law MR, Hudson ME, Heard BE. Malignant mesothelioma of the pleura: relationship between histological type and clinical behaviour. Thorax 1982;37:810-5.

28 Gibbs AR, Jones JSP, Pooley FD, Griffiths DM, Wagne JC. Non-occupational malignant mesotheliomas. In Bignon J, Peto J, Saracci R, eds. Non-occupational exposure to mineral fibres. IARC Scientific Publications No 90. Lyon: IARC, 1989:219-28.

29 Kannerstein M, Churg J. Peritoneal mesothelioma. Hum Pathol 1977;8:83-94.

30 Hirsch A, Brochard P, De Cremoux H, Erkan L, Sebastien P, Di Menza L, et al. Features of asbestosexposed and unexposed mesothelioma. Am $\mathrm{F}$ Ind Med 1982;3:413-22.

31 McDonald AD, McDonald JC, Pooley FD. Mineral fibre content of lung in mesothelial tumour in North America. Ann Occup Hyg 1982;26:417-22.

32 Wagner JC, Newhouse ML, Corrin BB, Rossiter CE, Griffiths DM. Correlation between lung fibre conten and disease in East London asbestos factory workers. In: Bignon J, Peto J, Saracci R, eds. Non-occupational exposure to mineral fibres. IARC Scientific Publications No 90. Lyon: IARC, 1989:444-8.

33 Kannerstein M, Churg J, McCaughey WTE, Hill DP. Papillary tumours of the peritoneum in women: mesothelioma or papillary carcinoma. Am $f$ Obstet mesothelioma or papilla

34 Bell DA, Scully RE. Serous borderline tumours of the peritoneum. Am F Surg Pathol 1990;14:230-9.

35 Wagner JC, Moncrieff CB, Coles R, Griffiths DM, Munday DE. Correlation between fibre content of the lungs and disease in naval dockyard workers. $B r \mathcal{F}$ Ind Med 1986;43:391-5.

36 Wagner JC, Pooley FD, Berry G, Seal RME, Munday $\mathrm{DE}$, Morgan J, et al. A pathological and mineralogical study of asbestos-related deaths in the United Kingdom in 1977. Ann Occup Hyg 1982;26:423-31.

37 Oels HC, Harrison EG, Carr DT, Bernatz PE. Diffuse malignant mesothelioma of the pleura: a review of 37 cases. Chest 1971;60:564-70.

38 Jones JSP, Pooley FD, Smith PG, Berry G, Sawle GW, Madeley RJ, et al. The consequences of exposure to asbestos dust in a wartime gas mask factory. In: Wagne JC, ed. Biological effects of mineral fibres. IARC Scientific Publications No 30. Lyon: IARC, 1980; 637-53.

39 Gylseth B, Mowe G, Wannag A. Fibre type and concentration in the lungs of workers in an asbestos cemen factory. Br f Ind Med 1983;40:375-9.

40 Wagner JC, Berry G, Pooley FD. Mesotheliomas and asbestos type in asbestos textile workers: a study of lung contents. BMF 1982;285:603-6.

41 Berry G, Rogers AJ, Pooley FD. Mesotheliomas: asbestos exposure and lung burden. In Bignon J, Peto J, Saracci $\mathrm{R}$, eds. Non-occupational exposure to mineral fibres. IARC Scientific Publications No 90. Lyon: IARC, 1989: 486-96.

42 Jones JSP, Pooley FD, Clark NJ, Owen WG, Roberts GH Smith PG, et al. The pathology and mineral content of lungs in cases of mesothelioma in the United Kingdom in 1976. In: Wagner JC, ed. Biological effects of mineral fibres. IARC Scientific Publications No 30. Lyon: IARC, 1980: 187-99.

43 Churg A, Wiggs B. Fibre size and number in workers exposed to processed chrysotile asbestos, chrysotile miners, and the general population. $\mathrm{Am} \mathcal{F}$ Ind $\mathrm{Med}$ 1986;9:143-52.

44 Pooley FD. An examination of the fibrous mineral conten of asbestos lung tissue from the Canadian chrysotile mining industry. Environ Res 1976;12:281-98.

45 Rowlands N, Gibbs GW, McDonald JC. Asbestos fibres in the lungs of chrysotile miners and millers. Ann Occup ing 1982;26:411-15.

46 Peterson JT, Greenberg SD, Buffler PA. Non-asbestos related malignant mesothelioma. Cancer 1984;54:951-60. 